\title{
The Effect of UV-Irradiation (under Short-Circuit Condition) on Dye-Sensitized Solar Cells Sensitized with a Ru-Complex Dye Functionalized with a (diphenylamino)Styryl-Thiophen Group
}

\author{
Kazuteru Nonomura, ${ }^{1}$ Yunhua Xu, ${ }^{1}$ Tannia Marinado, ${ }^{1}$ Daniel P. Hagberg, ${ }^{1}$ Rong Zhang, ${ }^{2}$ \\ Gerrit Boschloo, ${ }^{1,3}$ Licheng Sun, ${ }^{1}$ and Anders Hagfeldt ${ }^{1,3}$ \\ ${ }^{1}$ Department of Chemistry, Center of Molecular Devices, Royal Institute of Technology (KTH), Teknikringen 30, \\ 10044 Stockholm, Sweden \\ ${ }^{2}$ State Key Laboratory of Fine Chemicals, DUT-KTH Joint Education and Research Center on Molecular Devices, \\ Dalian University of Technology (DUT), Dalian 116012, China \\ ${ }^{3}$ Department of Physical and Analytical Chemistry, Uppsala University, Box 259, 75105 Uppsala, Sweden \\ Correspondence should be addressed to Kazuteru Nonomura, kazuteru@kth.se
}

Received 22 January 2009; Accepted 18 May 2009

Recommended by Mohamed Sabry Abdel-Mottaleb

\begin{abstract}
A new ruthenium complex, cis-di(thiocyanato) (2,2' -bipyridine-4,4'-dicarboxylic acid) (4,4'-bis (2-(5-(2-(4-diphenylaminophenyl)ethenyl)-thiophen-2-yl)ethenyl)-2,2'-bipyridine)ruthenium(II) (named E322) has been synthesized for use in dyesensitized solar cells (DSCs). Higher extinction coefficient and a broader absorption compared to the standard Ru-dye, N719, were aimed. DSCs were fabricated with E322, and the efficiency was $0.12 \%$ initially. ( $4.06 \%$ for N719, as reference). The efficiency was enhanced to $1.83 \%$ by exposing the cell under simulated sunlight containing UV-irradiation at short-circuit condition. The reasons of this enhancement are (1) enhanceing electron injection from sensitizer to $\mathrm{TiO}_{2}$ following a shift toward positive potentials of the conduction band of $\mathrm{TiO}_{2}$ by the adsorption of protons or cations from the sensitizer, or from the redox electrolyte and (2) improving the regeneration reaction of the oxidized dye by the redox electrolyte by the dissolution of aggregated dye from the surface of $\mathrm{TiO}_{2}$ following the treatment.
\end{abstract}

Copyright (C) 2009 Kazuteru Nonomura et al. This is an open access article distributed under the Creative Commons Attribution License, which permits unrestricted use, distribution, and reproduction in any medium, provided the original work is properly cited.

\section{Introduction}

Dye-sensitized solar cells have been intensively investigated in the last decades after Graetzel and his coworkers showed more than $10 \%$ of sun light to electrical power conversion efficiency $[1,2]$. Conventionally, a porous nanocrystalline $\mathrm{TiO}_{2}$ thin film, Ru-complex dye molecules, and $\mathrm{I}^{-} / \mathrm{I}_{3}{ }^{-}$redox couple are used. Ideal sensitizers for dye-sensitized solar cells should have a broad absorption spectrum to utilize the visible light, good charge separation property, and good energy matching with the conduction band of $\mathrm{TiO}_{2}$ and the redox potential of electrolyte. A lot of $\mathrm{Ru}$-complex dyes have been developed to achieve this goal [2-12]. For example, dyes such as N3, N719, and black dye are known as suitable dyes fulfilling the conditions mentioned above. However, it is still a key issue to further develop sensitizers for dyesensitized solar cells to improve the efficiency. A way to improve the efficiency is the development of a dye which has higher extinction coefficients. Such sensitizers allow the use of thinner $\mathrm{TiO}_{2}$ nanocrystalline films, which is beneficial as it will reduce the recombination of electrons with redox electrolyte during electron transport to the external circuit. Considering solid states dye-sensitized solar cells, thinner semiconductor layer will also be required. Another way to improve the sensitizer is by improving the intramolecular charge separation. By attaching functional groups to $\mathrm{Ru}$ complex dyes, further charge separation of the HOMO and LUMO is aimed for. Such a structure is expected to promote electron injection into $\mathrm{TiO}_{2}$ and delays subsequent recombination [13]. 


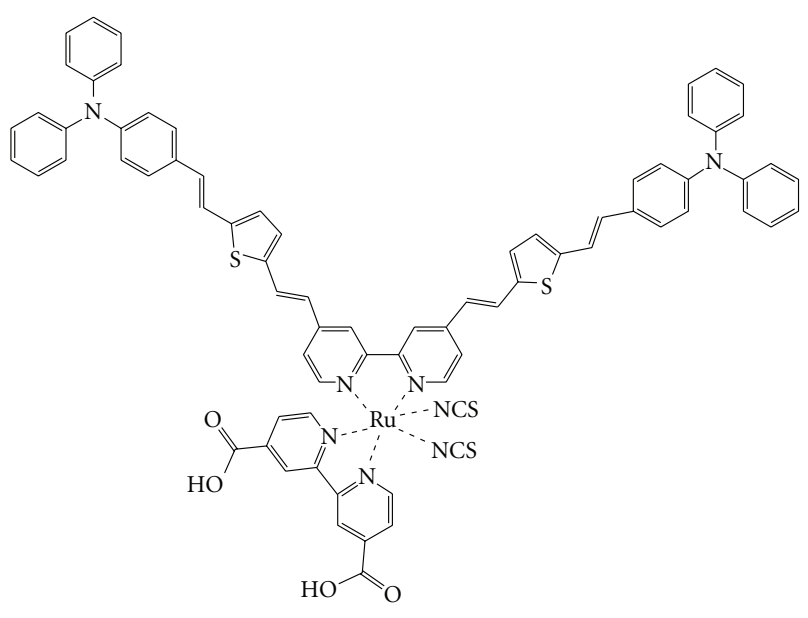

Figure 1: Molecular structure of E322.

We have recently reported a polyene-triphenylamine dye, named D5, which showed a good charge separation and almost the same light to electric conversion efficiency in dye-sensitized solar cell as N719 under comparable condition [14]. Quantum chemical calculations suggest that the dye has a clear intramolecular charge separation following the excitation. In this study, we attached polyenetriphenylamine to the bipyridine ligand of an Ru-complex dye to improve the extinction coefficient of the dye as well as to aim for a broad absorption in the visible-near infrared light region. The dye we have synthesized for this study is cis-di(thiocyanato $)\left(2,2^{\prime}\right.$-bipyridine- $4,4^{\prime}$-dicarboxylic acid) (4,4' -bis (2-(5-(2-(4-diphenylaminophenyl)ethenyl)thiophen-2-yl)ethenyl)-2,2'-bipyridine)ruthenium(II) (hereafter E322) (Figure 1).

Electrochemical characterization has been carried out to estimate the position of HOMO and LUMO potentials. The dye-modified $\mathrm{TiO}_{2}$ nanoporous thin films were characterized by photoinduced absorption spectroscopy (PIA). Photoelectrochemical properties of the fabricated cells were characterized by current-voltage (I-V) measurement, incident photon to current conversion efficiency (IPCE), and measurement of the electron life time and accumulated charge. As reference, DSCs sensitized with N719 were also prepared, and their properties were compared.

\section{Experimental}

2.1. Materials. The synthesis of ligand $\mathbf{1}$ and complex $\mathbf{2}$ can be found in the Supporting Information.

Complex 3. Ligand 1 (316 mg, $0.347 \mathrm{mmol}$ ) and complex $2(210 \mathrm{mg}, 0.347 \mathrm{mmol})$ were reacted in DMF $(30 \mathrm{~mL})$ at $140^{\circ} \mathrm{C}$ for 8 hours. DMF was removed, and the residue was recrystallized from a mixture of $\mathrm{CH}_{2} \mathrm{Cl}_{2}$ and acetone. The black precipitate formed was collected, washed with cold acetone, and dried, giving the product $(410 \mathrm{mg}, 85 \%$ yield $)$. ${ }^{1} \mathrm{H}$ NMR $\left(500 \mathrm{MHz}, \mathrm{DMSO}-\mathrm{d}_{6}\right): \delta=1.31(\mathrm{t}, J=7.0 \mathrm{~Hz}$, $3 \mathrm{H}), 1.44(\mathrm{t}, J=7.0 \mathrm{~Hz}, 3 \mathrm{H}), 4.35(\mathrm{q}, J=7.0 \mathrm{~Hz}, 2 \mathrm{H}), 4.50$ $(\mathrm{q}, J=7.0 \mathrm{~Hz}, 2 \mathrm{H}), 6.85(\mathrm{~d}, J=16.0 \mathrm{~Hz}, 1 \mathrm{H}), 6.92-6.97$ $(\mathrm{m}, 5 \mathrm{H}), 7.00(\mathrm{~d}, J=16.0 \mathrm{~Hz}, 1 \mathrm{H}), 7.04-7.17(\mathrm{~m}, 15 \mathrm{H}), 7.24$ $(\mathrm{d}, J=3.5 \mathrm{~Hz}, 1 \mathrm{H}), 7.27-7.40(\mathrm{~m}, 13 \mathrm{H}), 7.48(\mathrm{~d}, J=8.5 \mathrm{~Hz}$, $2 \mathrm{H}), 7.52-7.54(\mathrm{~m}, 3 \mathrm{H}), 7.83(\mathrm{~d}, J=16.0 \mathrm{~Hz}, 1 \mathrm{H}), 7.91(\mathrm{~d}$, $J=6.0 \mathrm{~Hz}, 1 \mathrm{H}), 7.93(\mathrm{~s}, 1 \mathrm{H}), 8.07(\mathrm{~d}, J=16.0 \mathrm{~Hz}, 1 \mathrm{H})$, $8.19(\mathrm{~d}, J=6.0 \mathrm{~Hz}, 1 \mathrm{H}), 8.71(\mathrm{~s}, 1 \mathrm{H}), 8.86(\mathrm{~s}, 1 \mathrm{H}), 8.88(\mathrm{~s}$, $1 \mathrm{H}), 9.04(\mathrm{~s}, 1 \mathrm{H}), 9.73(\mathrm{~d}, J=6.0 \mathrm{~Hz}, 1 \mathrm{H}), 10.22 \mathrm{ppm}(\mathrm{d}$, $J=6.0 \mathrm{~Hz}, 1 \mathrm{H})$. MALDI-TOF MS: $\mathrm{m} / z=1365.719$ (calcd for $\left.\left[\mathrm{M}-\mathrm{Cl}^{-}+\mathrm{H}_{2} \mathrm{O}\right]^{+}: 1365.311\right)$.

Complex 4. A mixture of 3 (300 mg, $0.217 \mathrm{mmol}$ ) and $\mathrm{NH}_{4} \mathrm{NCS}$ (400 mg, $5.26 \mathrm{mmol}$ ) in DMF $(50 \mathrm{~mL})$ was heated at $130^{\circ} \mathrm{C}$ for 48 hours. Upon cooling, solvent was removed, and the residue was dissolved in $\mathrm{CH}_{2} \mathrm{Cl}_{2}$ and washed with saturated aqueous solution of $\mathrm{Na}_{2} \mathrm{CO}_{3}$. The organic phase was dried over $\mathrm{Na}_{2} \mathrm{SO}_{4}$. After solvent removal, the crude product was purified by column chromatography on $\mathrm{SiO}_{2}$ using $0.2 \% \mathrm{MeOH}$ in $\mathrm{CH}_{2} \mathrm{Cl}_{2}$ as eluent to give the desired product (190 mg, 61\% yield). ${ }^{1} \mathrm{H}$ NMR (500 MHz, DMSO$\left.\mathrm{d}_{6}\right): \delta=1.30(\mathrm{t}, J=7.0 \mathrm{~Hz}, 3 \mathrm{H}), 1.42(\mathrm{t}, J=6.5 \mathrm{~Hz}, 3 \mathrm{H})$, $4.36(\mathrm{q}, J=7.0 \mathrm{~Hz}, 2 \mathrm{H}), 4.47(\mathrm{q}, J=7.0 \mathrm{~Hz}, 2 \mathrm{H}), 6.82(\mathrm{~d}$, $J=15.0 \mathrm{~Hz}, 1 \mathrm{H}), 6.92-7.01(\mathrm{~m}, 5 \mathrm{H}), 7.04-7.12(\mathrm{~m}, 13 \mathrm{H})$, 7.16-7.28 (m, 5H), 7.31-7.37 (m, 10H), 7.40-7.43 (m, 2H), $7.49(\mathrm{~d}, J=8.5 \mathrm{~Hz}, 2 \mathrm{H}), 7.53(\mathrm{~d}, J=8.5 \mathrm{~Hz}, 2 \mathrm{H}), 7.65$ $(\mathrm{d}, J=6.0 \mathrm{~Hz}, 1 \mathrm{H}), 7.84(\mathrm{~d}, J=16.0 \mathrm{~Hz}, 1 \mathrm{H}), 7.89(\mathrm{~d}$, $J=6.0 \mathrm{~Hz}, 2 \mathrm{H}), 7.96-8.02(\mathrm{~m}, 1 \mathrm{H}), 8.24(\mathrm{~s}, \mathrm{br}, 1 \mathrm{H}), 8.50-$ $8.80(\mathrm{~m}, 2 \mathrm{H}), 8.96(\mathrm{~s}, 1 \mathrm{H}), 9.04(\mathrm{~d}, J=5.5 \mathrm{~Hz}, 1 \mathrm{H}), 9.11$ (s, $1 \mathrm{H}), 9.49 \mathrm{ppm}(\mathrm{d}, J=5.5 \mathrm{~Hz}, 1 \mathrm{H})$. MALDI-TOF MS: $m / z=1370.279\left(\right.$ calcd for $\left.\left[\mathrm{M}-\mathrm{NCS}^{-}\right]^{+}: 1370.307\right)$.

Complex E322. A solution of complex 4 (94 mg, $0.066 \mathrm{mmol}$ ) in THF $(20 \mathrm{~mL})$ containing $\mathrm{NaOH}$ (excess, aqueous solution) was heated at $70^{\circ} \mathrm{C}$ for 12 hours. After cooling to room temperature, solvent was removed, and the residue was dissolved in a mixture of THF/ $\mathrm{H}_{2} \mathrm{O}(1: 1)$ and passed through a Sephadex LH-20 column. Main band was collected, and the $\mathrm{pH}$ was lowered to 2 by adding dilute aqueous $\mathrm{HNO}_{3}$ solution. The precipitate was filtered and washed with water and methanol and dried, giving complex E322 (114 mg, 85\% yield). ${ }^{1} \mathrm{H}$ NMR (500 MHz, DMSO- $\mathrm{d}_{6}$ ): $\delta=6.89(\mathrm{~d}, J=16.0 \mathrm{~Hz}, 1 \mathrm{H}), 6.92(\mathrm{~d}, J=8.5 \mathrm{~Hz}, 2 \mathrm{H}), 6.95$ $(\mathrm{d}, J=8.5 \mathrm{~Hz}, 2 \mathrm{H}), 7.01(\mathrm{~d}, J=16.0 \mathrm{~Hz}, 1 \mathrm{H}), 7.04-7.12$ $(\mathrm{m}, 13 \mathrm{H}), 7.18(\mathrm{~d}, J=3.5 \mathrm{~Hz}, 1 \mathrm{H}), 7.25(\mathrm{~d}, J=3.5 \mathrm{~Hz}$, $1 \mathrm{H}), 7.27-7.39(\mathrm{~m}, 14 \mathrm{H}), 7.41(\mathrm{~d}, J=3.5 \mathrm{~Hz}, 1 \mathrm{H}), 7.49(\mathrm{~d}$, $J=9.0 \mathrm{~Hz}, 2 \mathrm{H}), 7.53(\mathrm{~d}, J=9.0 \mathrm{~Hz}, 2 \mathrm{H}), 7.65(\mathrm{~d}, J=6.0 \mathrm{~Hz}$, $1 \mathrm{H}), 7.85(\mathrm{~s}, 1 \mathrm{H}), 7.88(\mathrm{~d}, J=5.5 \mathrm{~Hz}, 1 \mathrm{H}), 8.03-8.10(\mathrm{~m}$, $2 \mathrm{H}), 8.29(\mathrm{~d}, J=5.5 \mathrm{~Hz}, 1 \mathrm{H}), 8.74(\mathrm{~s}, \mathrm{br}, 1 \mathrm{H}), 8.86-8.94$ (m, 2H), 9.07 (s, 1H), 9.09 (d, J = 5.5 Hz, 1H), $9.45 \mathrm{ppm}(\mathrm{d}$, $J=6.0 \mathrm{~Hz}, 1 \mathrm{H})$. MALDI-TOF MS: $m / z=1314.609$ (calcd for $\left[\mathrm{M}-\mathrm{H}^{+}+\mathrm{K}^{+}-\mathrm{NCS}\right]^{+}$: 1314.248).

Absorption spectra of the dye solution and dye modified $\mathrm{TiO}_{2}$ thin films were measured with HR-2000 Ocean Optics, fiber optics spectrophotometer. $\mathrm{CH}$ Instruments 660 Potentiostat was used for differential pulse voltammetry. Electrochemical analysis was carried out in $1 \mathrm{mM}$ dye and $0.1 \mathrm{M}$ of tetrabutylammonium hexafluorophosphate $\left(\mathrm{TBAPF}_{6}\right.$, Tokyo kasei kogyo) in tetrahydrofuran (THF, Aldrich, 99.9\%). A platinum electrode, a platinum wire, and 
$\mathrm{Ag} / \mathrm{Ag}^{+}$electrode were used as working electrode, counter electrode, and reference electrode, respectively. The obtained potentials were adjusted by comparing the redox potential of the Ferrocene/Ferrocenium redox couple.

For the preparation of $\mathrm{TiO}_{2}$ films, conducting glass substrates (TEC8, Pilkington) were covered by Scotch-tape (3M) with a rectangular shaped hole $(8 \mathrm{~mm} \times 4 \mathrm{~mm})$ at the center. $\mathrm{TiO}_{2}$ nanocrystalline thin films were prepared by spreading a suspension onto the conducting glass substrates. A single deposition gave a $3 \mu \mathrm{m}$ thick film. The data shown in Table 2 were obtained from a film which thickness was ca. $9 \mu \mathrm{m}$. To study the effect of UV irradiation, $3 \mu \mathrm{m}$ thick films were used. The area of the $\mathrm{TiO}_{2}$ film was $0.32 \mathrm{~cm}^{2}$. $\mathrm{TiO}_{2}$ electrodes were sintered at $450^{\circ} \mathrm{C}$ for 30 minutes. The electrodes were put into the dye bath when the temperature cooled down to $80^{\circ} \mathrm{C}$ and kept for 24 hours at room temperature. The concentration of the dye was $0.5 \mathrm{mM}$. The solvent was ethanol (Kemetyl, 99.5\%) and tetrahydrofuran for N719 purchased from solaronix S.A and E322, respectively.

The electrodes were assembled with a counter electrode (thermally platinized TEC8) using a thermoplastic frame. Redox electrolyte was introduced through a hole drilled in the counter electrode that was sealed afterward. The electrolyte was composed of $0.1 \mathrm{M}$ LiI (Aldrich, 99.9\%), $0.6 \mathrm{M}$ TBAI (tetrabutyl ammonium iodide, Sigma-aldrich, 98\%), 0.05 $\mathrm{M} \mathrm{I}_{2}$ (Aldrich, 99.999\%), and 0.5 M 4-TBP (4tert-butylpyridine, Aldrich, 99\%) in Acetonitrile (Aldrich, 99.8\%). Prepared solar cells were characterized by IV measurements and various "tool-box" techniques [15]. A xenon arc lamp ( $300 \mathrm{~W}$ Cermax, ILC Technology) with filter (Tempax 113, Schott) was used as light source for IV measurements. The light intensity was adjusted to $1000 \mathrm{~W} \mathrm{~m}^{-2}$. IPCE was measured by using a computerized setup consisting of a xenon arc lamp (300 W Cermax, ILC Technology), a 1/8 m monochromator (CVI Digikröm CM 110), and a Keithley 2400 source/meter. The amounts of charge, open circuit photovoltage, and electron lifetime in the dye-sensitized solar cells were measured in a system using a red-light-emitting diode (Luxeon Star $1 \mathrm{~W}, \lambda_{\max }=640 \mathrm{~nm}$ ) as the light source. The relation between potential and charge was investigated using a combined voltage decay/charge extraction method. The solar cell was illuminated for 5 seconds under open circuit conditions, and the voltage was left to decay for a certain period in the dark to a voltage V. Subsequently, the cell was short-circuited, and the current was measured and integrated over 10 seconds to obtain $\mathrm{Q}_{\mathrm{oc}}(\mathrm{V})$. Electron lifetimes were determined by monitoring the transient photovoltage response after a small change in light intensity. A square wave modulation $(<10 \%$ intensity) was added to the base light intensity, and the step response was recorded using the DAQ (data acquisition) board. The current and voltage responses were fitted using first-order decay kinetics, and time constants were obtained accordingly.

Photoinduced absorption spectroscopy (PIA) was carried out for the prepared electrodes. PIA measurements were performed using white probe light (a tungsten-halogen lamp) and superimposed on/off modulated blue light $(450 \mathrm{~nm})$ from an LED (Luxeon 1 Watt Star, Royal Blue) for excitation. The transmitted probe light was focused onto a monochromator (Acton Research Corporation SP-150) and detected by an UV enhanced silicon photodiode connected to a current amplifier and lock-in amplifier (Stanford Research Systems models SR570 and SR830, resp.). PIA measurements were performed slightly above room temperature $\left(25-28^{\circ} \mathrm{C}\right)$. PIA measurements were also carried out in the presence of the electrolyte.

\section{Results and Discussion}

3.1. Synthesis. The synthesis of the dye started from the reaction of the ligand $\mathbf{1}$ with the ruthenium complex $\mathbf{2}$, which afforded the dichloro ruthenium complex 3 . The two chlorides in complex $\mathbf{3}$ were replaced with thiocyanates by refluxing the mixture of 3 and excess $\mathrm{NH}_{4} \mathrm{NCS}$ in DMF, giving complex $\mathbf{4}$. Ester groups in $\mathbf{4}$ were hydrolyzed in the presence of $\mathrm{NaOH}$ in acetonitrile followed by acidification to afford the final product E322. All the ruthenium complexes were characterized by ${ }^{1} \mathrm{H}$ and ${ }^{13} \mathrm{C}$ NMR and MS spectroscopy.

The absorption spectra of E322 and N719 in THF and ethanol, respectively, are shown in Figure 2. The extinction coefficient of E322 at the absorption maximum at $469 \mathrm{~nm}$ is $4.2 \times 10^{4} \mathrm{M}^{-1} \mathrm{~cm}^{-1}$. Compared to the extinction coefficient of N719 which is $1.3 \times 10^{4} \mathrm{M}^{-1} \mathrm{~cm}^{-1}$ at $518 \mathrm{~nm}$ in ethanol solution [16], the obtained extinction coefficient for E322 is 3 times higher. The spectrum of E322 is very broad. Although the absorption peak of E322 is blue shifted compared to N719, the extinction coefficient of E322 exceeds that of N719 in the whole visible range and has an onset that is more than $100 \mathrm{~nm}$ red-shifted.

The oxidation potential and the reduction potential of the dye were measured by differential pulse voltammetry. The HOMO potential of the dyes was estimated from the oxidation potential. Obtained values are listed in Table 1. $E_{0-0}$ was estimated from the tail of the absorption spectrum in the longer wavelength region. From these two values, the LUMO potential was estimated. The obtained values fulfill the conditions required for dye-sensitized solar cells; the potential of the LUMO is higher than the conduction band of $\mathrm{TiO}_{2}$, and the potential of the HOMO is lower than the potential of the redox electrolyte [17].

Photocurrent action spectra were measured for E322 and N719 and are shown in Figure 3. It can be seen for all the dyes that photocurrents were generated from a rather wide range of the visible light. IPCE of $50 \%$ and $27 \%$ was obtained at $540 \mathrm{~nm}$ for N719 and E322, respectively. Comparing the shape of the action spectra, E322 has a broader spectral response than N719. However, the IPCE at $540 \mathrm{~nm}$ for E322 is lower than N719. It should be noted that an IPCE value of $27 \%$ for E322 was obtained after treating the cell with simulated sunlight containing UV under short-circuit condition. When no treatment was introduced, the value of IPCE at $540 \mathrm{~nm}$ is virtually zero, $0.45 \%$. The details for this intriguing observation are discussed below.

The results of solar cell characterization are shown in Table 2. 

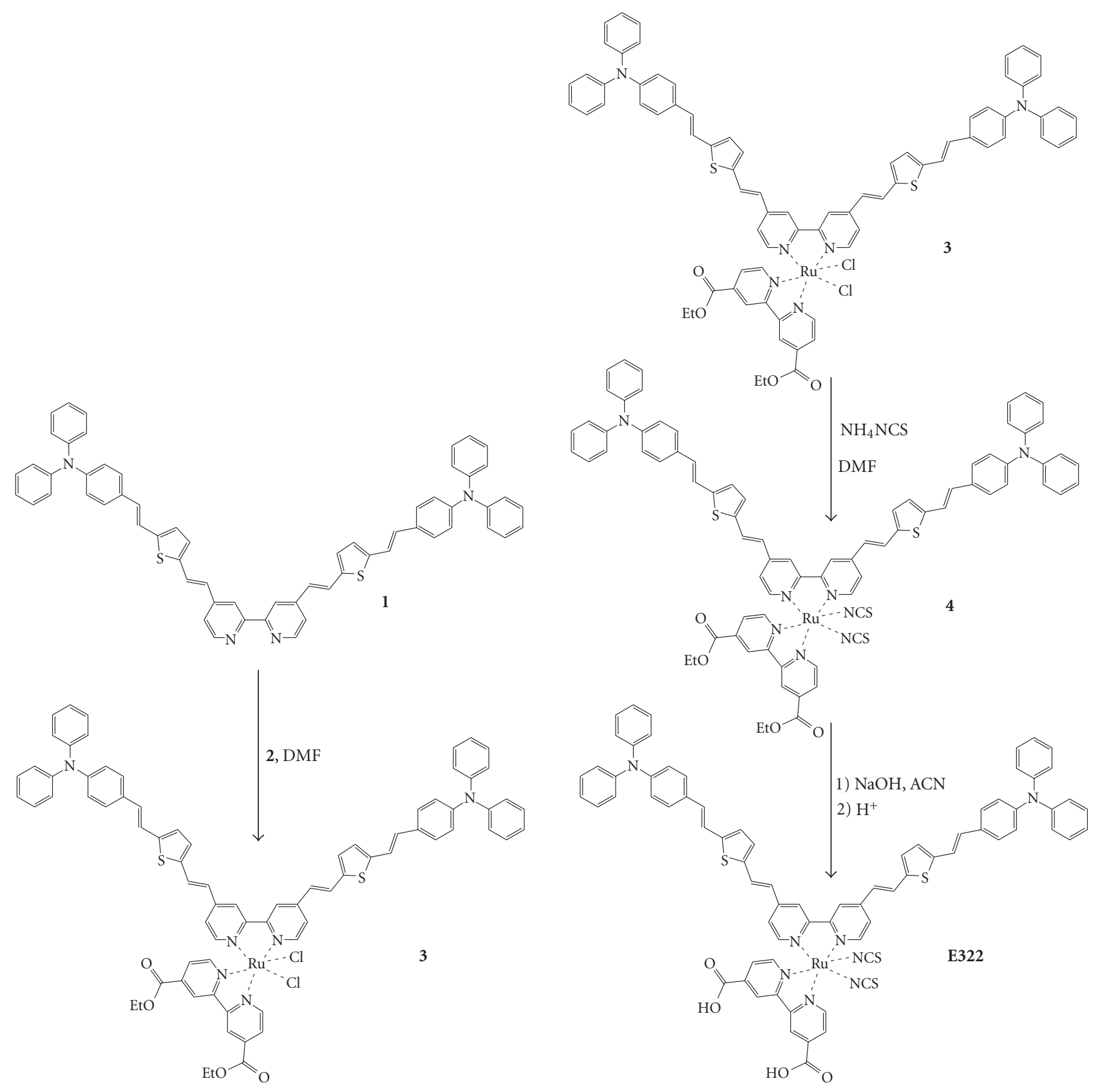

Scheme 1: Synthesis of E322.

Although E322 has a high extinction coefficient and the film is deeply colored by the dye, the photocurrent under short-circuit condition, $I_{\mathrm{sc}}$, is lower than for N719. The opencircuit photovoltage, $V_{\text {oc }}$, of the cells with E322 was $0.54 \mathrm{~V}$, while $V_{\text {oc }}$ of $\mathrm{N} 719$ was $0.77 \mathrm{~V}$. The fill factor, ff, showed a similar tendency as $V_{\mathrm{oc}}$, relatively high for N719 and low for E322. Consequently, the cell with N719 showed a higher conversion efficiency of $4.1 \%$, compared to $1.8 \%$ for the cells with E322. It should be noted that the optimizations of the cell, such as a blocking layer and scattering layers, to obtain higher efficiencies have not been introduced in this study. It should also be noted that the efficiency of $1.8 \%$ for E322 was obtained after exposing the cell to the simulated solar light containing UV light at short circuit condition for 70 hours.

When the solar cell sensitized with E322 was irradiated with simulated solar light under short circuit condition, the photocurrent increased gradually and reached a plateau (Figure 4).

Before applying this treatment, the efficiency of the cell was $0.12 \%$ (Table 2). The efficiency was enhanced more than 10 times by employing the UV treatment. The time to reach the plateau depends on the amount of the adsorbed dye. The time to reach the plateau for lightly colored films was shorter than deeply colored films. This phenomenon only occurred 
TABLE 1: Experimental data for electrochemical and spectral properties of the dyes.

\begin{tabular}{|c|c|c|c|c|c|c|}
\hline Dye & $E_{\mathrm{D} / \mathrm{D}+}[\mathrm{V}]$ vs. NHE & $E_{\text {red }}[\mathrm{V}]$ vs. NHE & $E_{(\mathrm{o}-\mathrm{o})}{ }^{(\mathrm{b})}[\mathrm{eV}]$ & $E_{\mathrm{D}^{*} / \mathrm{D}+}{ }^{(\mathrm{c})}[\mathrm{V}]$ & $\lambda_{\max }[\mathrm{nm}]$ & Extinction coefficient $\left[\mathrm{M}^{-1} \mathrm{~cm}^{-1}\right]$ \\
\hline E322 & $0.74^{(\mathrm{a})}$ & $-0.93^{(\mathrm{a})}$ & 1.55 & -0.81 & 469 & $4.2 \times 10^{4}$ \\
\hline N719 & $1.13^{(\mathrm{d})}$ & $-1.16^{(\mathrm{d})}$ & 1.88 & -0.75 & 518 & $1.3 \times 10^{4}$ \\
\hline
\end{tabular}

(a) oxidation potential and reduction potential were measured from differential pulse voltammetry in $1 \mathrm{mM} \mathrm{E} 322$ and $0.1 \mathrm{M} \mathrm{TBAPF}_{6}$ in THF, ${ }^{(b)} E_{\mathrm{O}-\mathrm{o}}$ energy was estimated from the wavelength at the tail of the absorption in longer wavelength, ${ }^{(c)} E_{\mathrm{D}^{*} / \mathrm{D}+}$ was estimated from oxidation potential and $E_{\mathrm{O}-\mathrm{o}}$ energy, ${ }^{(d)}$ values were obtained by referring the value $E_{\mathrm{ox}}=0.5 \mathrm{~V}$ vs. Fc and $E_{1 / 2}=-1.79 \mathrm{~V}$ vs. Fc from [7] and indicated vs. NHE by using the redox potential of ferrocene (0.63 V vs. NHE).

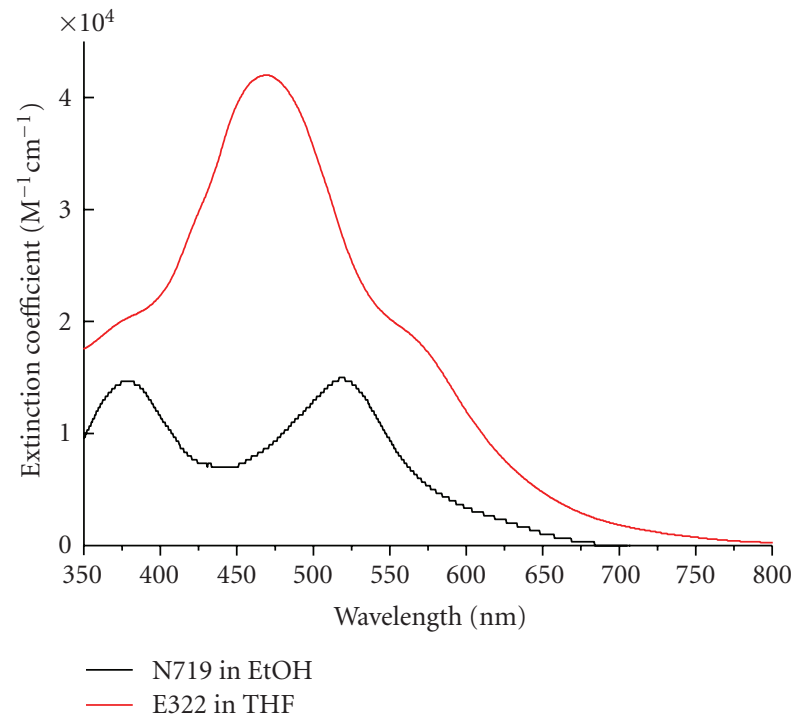

Figure 2: Absorption spectrum of the dye solution. THF and ethanol were used as solvent for E322 and N719, respectively.

TABLE 2: Photovoltaic performance of dye-sensitized solar cells with E322 and N719, respectively.

\begin{tabular}{lcccc}
\hline Dye & $J_{\mathrm{sc}} / \mathrm{mA} \mathrm{cm}^{-2}$ & $V_{\mathrm{oc}} / \mathrm{V}$ & $\mathrm{ff}$ & Efficiency $/ \%$ \\
\hline $\begin{array}{l}\text { E322 (after } \\
\text { treatment) }\end{array}$ & 5.41 & 0.538 & 0.630 & 1.83 \\
$\begin{array}{l}\text { E322 (before } \\
\text { treatment) }\end{array}$ & 0.55 & 0.414 & 0.534 & 0.12 \\
N719 & 7.47 & 0.770 & 0.707 & 4.06 \\
\hline
\end{tabular}

when the following conditions were fulfilled: UV light and short circuit condition.

To explain these phenomena, possible reasons are suggested: (1) dye degradation, (2) higher electron injection efficiency, (3) longer electron lifetime in $\mathrm{TiO}_{2}$, that is, due to reduced recombination of the electrons in the $\mathrm{TiO}_{2}$ with oxidized dyes or species in the electrolyte, and (4) more efficient regeneration reaction. These reasons can be rationalized as follows. First, if dye molecules are degraded by UV irradiation and if the degraded dye molecules are more efficient as sensitizers, then the cell performance can be enhanced. Second, the electron injection efficiency can be low due to either dye aggregation or unmatched energy levels between the LUMO of the dye and the conduction band of $\mathrm{TiO}_{2}$. If these unsuitable conditions are altered by the UV

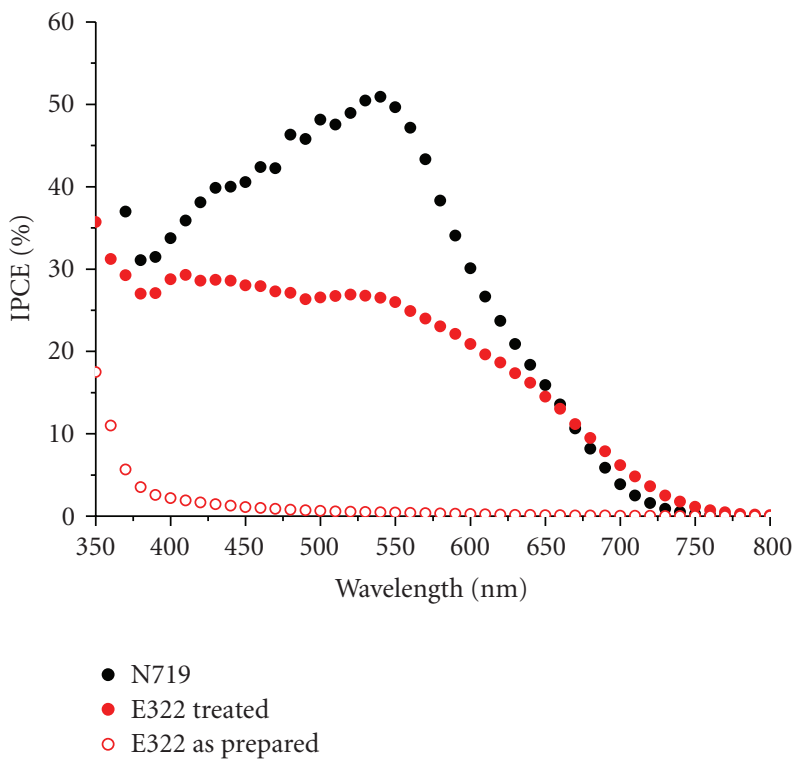

FIGURE 3: Action spectra of dye-sensitized solar cells with E322 and N719, respectively.

treatment, an enhanced efficiency can be obtained. Third, if the electron lifetime in $\mathrm{TiO}_{2}$ is short due to unfavorable interactions among aggregated dyes and if the electron lifetime increases by decreasing these interactions, this can be another reason of the enhancement of the efficiency. Fourth, if the regeneration of the oxidized dye by the redox electrolyte was blocked by the aggregated dyes and if this blocking was reduced by UV treatment, the efficiency can be enhanced. Those possible reasons are examined in the following section.

A possible reason of the enhanced efficiency after the UV treatment under short-circuit condition can be the photodegradation of the E322 resulting in a better sensitizer for the dye-sensitized solar cell. The absorption spectra of the dye solution, the dissolved dye from the surface of $\mathrm{TiO}_{2}$ after sensitization, and the dissolved dye from $\mathrm{TiO}_{2}$ after UV treatment were compared (see supporting information). The shapes of the absorption spectra were different between the dye solution and the desorbed dye from the surface of $\mathrm{TiO}_{2}$ after the sensitization. The peak wavelengths were, however, the same. The shapes of the absorption spectra between dissolved dye after sensitization and dissolved dye after UV treatment were very similar. The height of the absorption peak can, of course, vary by the amount of dye aggregation. Since the peak wavelengths are identical, it can be assumed that there is no degradation of the dye by introducing 


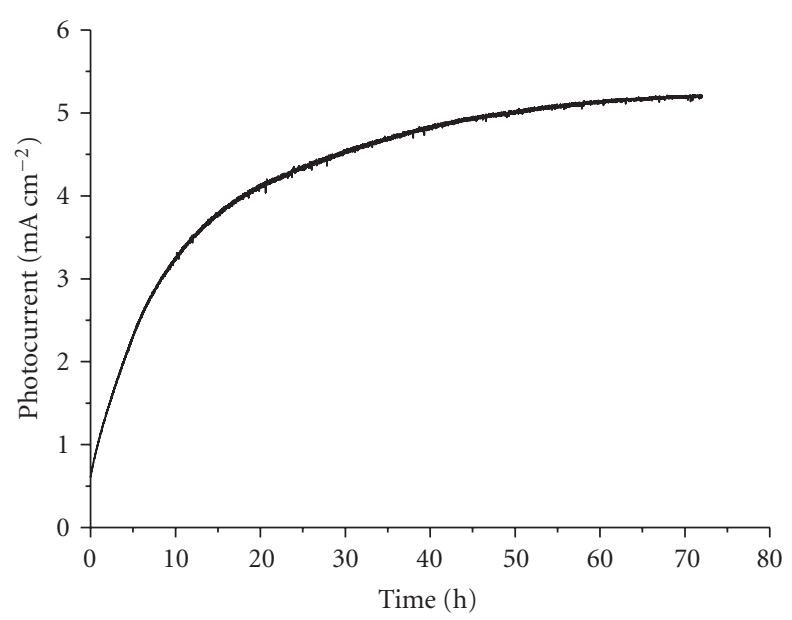

Figure 4: Time-current curve of the cell with E322. The short circuit photocurrent was recorded continuously at the light intensity of $1000 \mathrm{~W} \mathrm{~m}^{-2}$.

the UV irradiation treatment. Furthermore, the IR spectra before and after the treatment were very similar, confirming that no dye decomposition had occurred (See supporting information).

As a second possible reason, the electron injection efficiency can be improved by dissolving aggregates of the dye resulting in a more favorable monolayer of the sensitizer, and/or by shifting the conduction band in $\mathrm{TiO}_{2}$ to more positive potentials. To check the dye adsorption after the UV treatment, a solar cell assembled with lightly dyed film with E322 was dissembled after the treatment. The absorption spectrum of the electrode was measured and compared with the spectrum measured before fabricating the solar cell (Figure 5).

It is clearly seen that the absorption in the visible light region decreased after the treatment. Thus, we conclude that the dye desorbed from the surface of $\mathrm{TiO}_{2}$ during this treatment. Since the photocurrent increased after the treatment, the dye molecules which desorbed from the surface of $\mathrm{TiO}_{2}$ were not effective as sensitizers in the dyesensitized solar cells. These dyes acted as a filter for the incoming light. By comparing the absorption spectra of E322 and N719 on transparent $\mathrm{TiO}_{2}$ thin films, it was found that E322 is adsorbed at a 3 times higher concentration compared to N719 (see supporting information). A nearly monolayer adsorption can be expected in the case of N719 [18].

The conduction band shift of $\mathrm{TiO}_{2}$ was checked by charge extraction measurements. From these measurements, information of the relation between the accumulated charge in the film and open-circuit potential of the dye-sensitized solar cell can be obtained (Figure 6).

By comparing the voltage at the same amount of the accumulated charge in $\mathrm{TiO}_{2}$, it can be seen that the voltage is ca. $0.2 \mathrm{~V}$ less after the UV treatment compared to the value before the treatment. Since the amount of charge is the same, the shift of the voltage can be explained by the positive shift of the conduction band of $\mathrm{TiO}_{2}$ after the UV treatment [19-21]. This will promote the charge injection from the

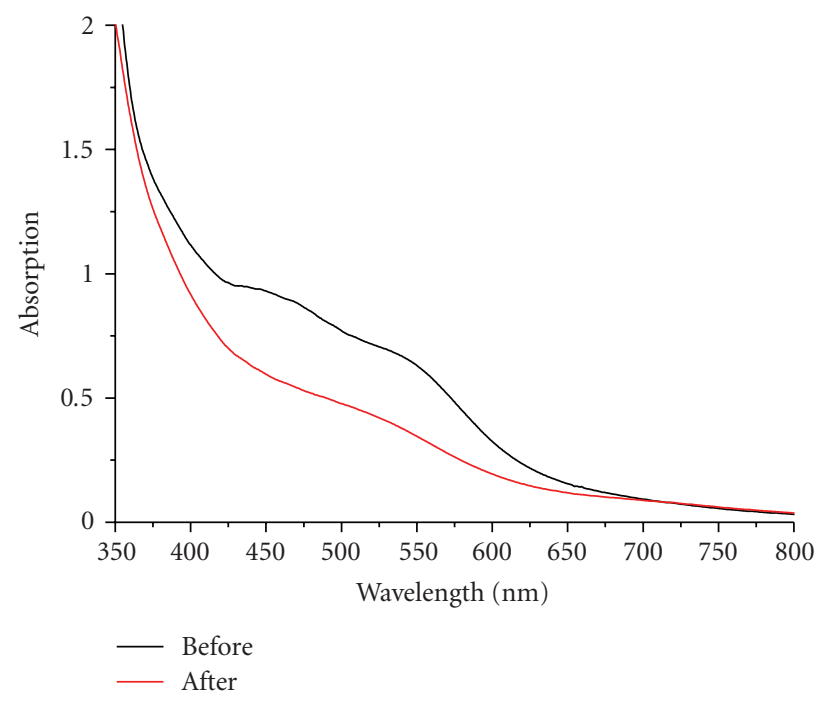

Figure 5: Absorption spectra of a $\mathrm{TiO}_{2}$ film $\left(3 \times 10^{-6} \mathrm{~m}\right.$ thick $)$ sensitized with E322 before and after employing the UV-light treatment. $\mathrm{SnO}_{2}$ glass substrate was used as reference.

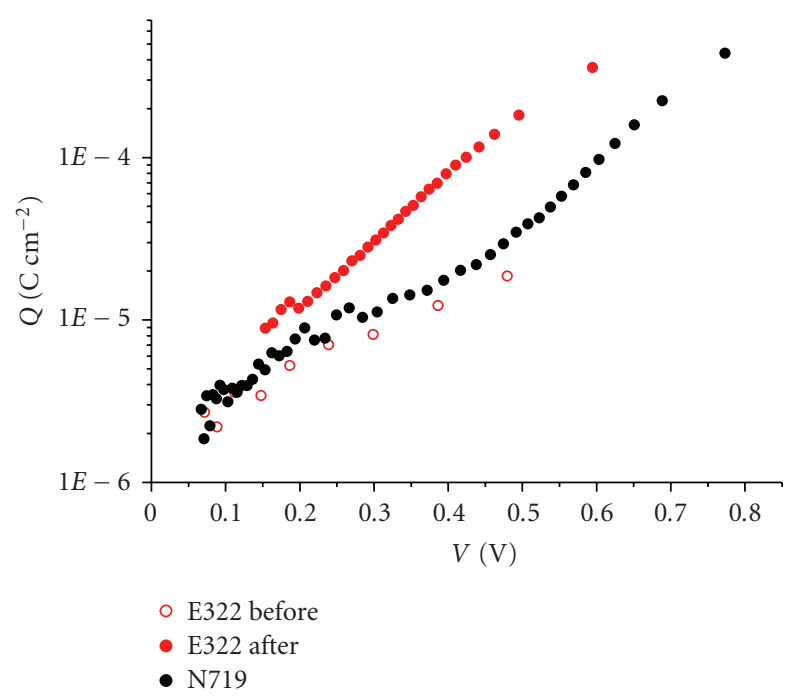

FIGURE 6: Extracted charge as a function of the open circuit photovoltage in dye-sensitized solar cell with E322 and N719. This measurement was carried out for the cell with E322 before and after employing the UV treatment.

excited dye to the conduction band of $\mathrm{TiO}_{2}$. The cause of the positive bandedge shift is a more positive surface charge of $\mathrm{TiO}_{2}$. This could be induced by the degradation of dye aggregates because of the treatment and/or the adsorption of protons or cations from the electrolyte. If these are the reasons for the enhanced efficiency, the efficiency should be initially high by the use of only $\mathrm{Li}^{+}$in the electrolyte since $\mathrm{Li}^{+}$is well known as a potential determining ion for $\mathrm{TiO}_{2}$ which shifts the conduction band to more positive potential [22-24]. When $0.1 \mathrm{M} \mathrm{LiI}$ and $0.05 \mathrm{M} \mathrm{I}_{2}$ was used as electrolyte, the short circuit photocurrent was ca. $3 \mathrm{~mA} \mathrm{~cm}^{-2}$ without any further treatment. This is ca. 5 times higher than the photocurrent with electrolyte containing the base 


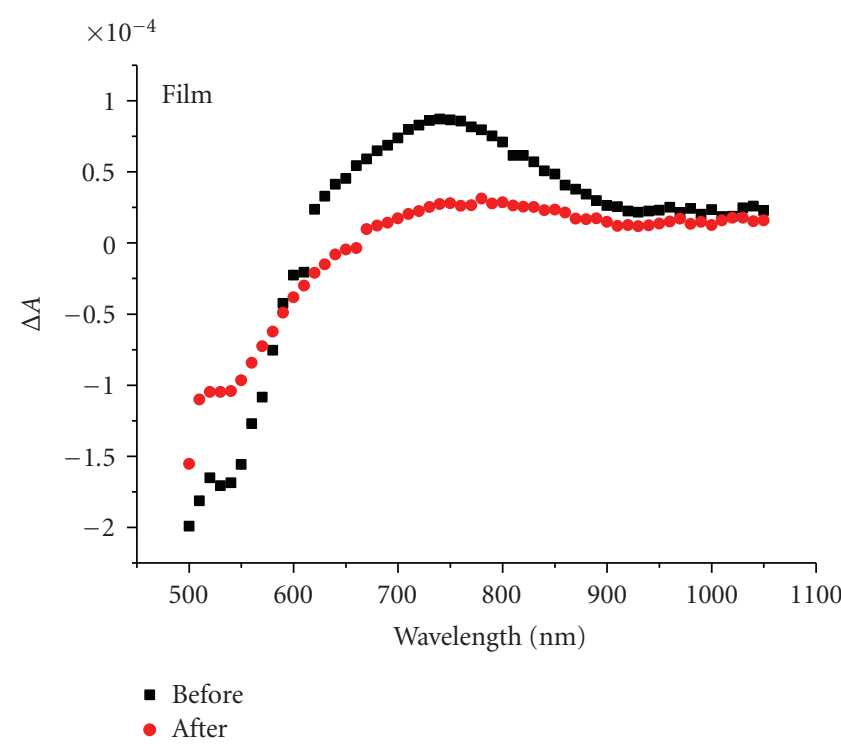

(a)

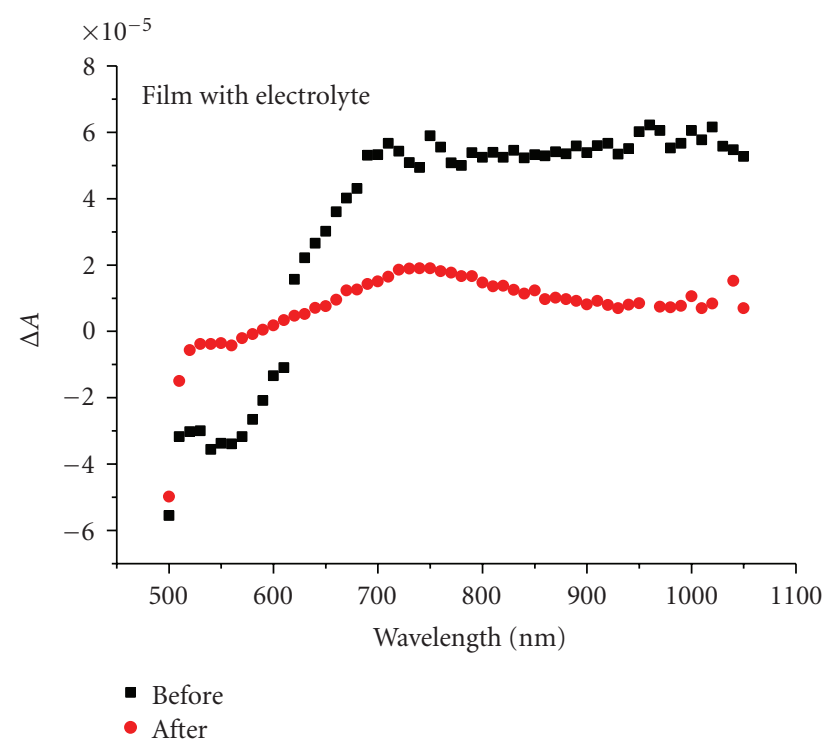

(b)

FIGURE 7: Photoinduced absorption spectra, excitation wavelength $450 \mathrm{~nm}$ with a frequency of $7 \mathrm{~Hz}, \mathrm{E} 322$ sensitized TiO ${ }_{2}$ thin film in the absent (a) and the present (b) of redox electrolyte. For both cases, the measurements were carried out before and after employing the UV treatment.

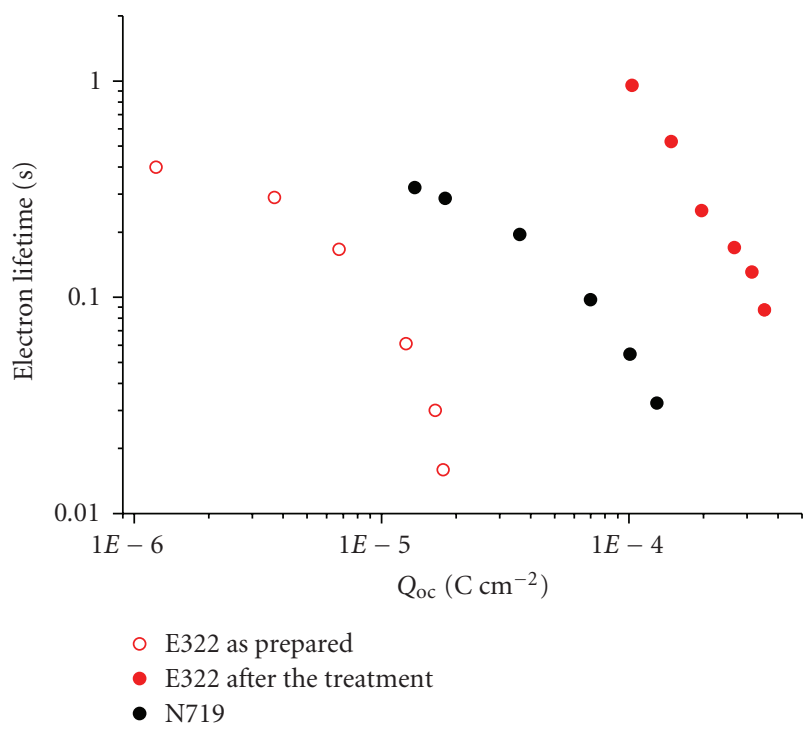

Figure 8: Electron lifetime as the function of the charge at open circuit condition, measured for the cell with E322 before/after the UV-treatment and the cell with N719.

additive, 4-tert-butylpyridine (4TBP). It indicates that an unmatched potential between the LUMO of the dye and the conduction band of $\mathrm{TiO}_{2}$ is a main reason for the low initial efficiency. Nevertheless, by introducing the UV treatment, the photocurrent increased to ca. $5 \mathrm{~mA} \mathrm{~cm}^{-2}$. This means that the conduction band shift is not the only reason for the enhancement of the efficiency. Aggregation and/or multilayer adsorption of the sensitizer is also hindering the performance of the solar cell.
Aggregation and/or multilayer adsorption of the sensitizers leads to inefficient regeneration of the oxidized dye from the redox electrolyte. This can be demonstrated with PIA $[25,26]$.

In the PIA spectrum of E322 on $\mathrm{TiO}_{2}$ (Figure 7(a)), a bleach can be observed at $545 \mathrm{~nm}$. It indicates that the sensitizer is in the oxidized form, which means that the injection of the electron from the sensitizer to the conduction band of $\mathrm{TiO}_{2}$ is occurring. In the presence of the redox electrolyte (Figure 7(b)), however, the bleach is still present. In highly efficient dye-sensitized solar cells, a bleach in PIA cannot be seen in the presence of redox electrolyte since the oxidized dyes are rapidly regenerated. In the case of N719 on $\mathrm{TiO}_{2}$, no bleach is seen in the presence of the redox electrolyte (not shown). These results indicate that the oxidized dye molecules are not fully regenerated by the redox electrolyte in the case of E322. After the UV treatment, on the other hand, the bleach disappears in PIA spectrum, suggesting that the oxidized dye is regenerated by the redox electrolyte. In addition to the favorable shift of the $\mathrm{TiO}_{2}$ conduction band for the injection process, the desorption of nonactive dye molecules allows for injecting dye molecules to be regenerated by the redox electrolyte.

The electron lifetime and the amount of the charge in the electrode were measured for a lightly dyed electrode before and after UV treatment (Figure 8). Before the UV treatment, the electron lifetime in the cell with E322 is about one order of magnitude shorter compared to the cell with N719. The interaction between aggregates or multilayer adsorption of E322 and the injected electron in $\mathrm{TiO}_{2}$ shortens apparently the electron lifetime. After the UV treatment, increase of the electron lifetime and more accumulated charge in the dye-modified $\mathrm{TiO}_{2}$ thin film electrode were detected 
compared to the results measured before the treatment. It is reasonable that the amount of charge in the dyemodified $\mathrm{TiO}_{2}$ thin film increases since both the injection and the regeneration process improve after the treatment. An efficient regeneration process reduces the recombination reaction between the electrons in the $\mathrm{TiO}_{2}$ and the oxidized dyes. The increased electron lifetime in the electrode seems to be caused by the decreased aggregation of the dye molecules. Moreover, the positive shift of the conduction band potential decreases the free energy difference between the $\mathrm{TiO}_{2}$ and redox electrolyte. This also decreases the driving force of the reaction between electrons in $\mathrm{TiO}_{2}$ and redox electrolyte.

Although the position of the $\mathrm{TiO}_{2}$ conduction band shifts positive by the UV treatment, the open-circuit photovoltage was increased by the larger amount of accumulated charge in the $\mathrm{TiO}_{2}$ film as implied by the increased amount of injected electrons and the longer electron lifetime.

It is peculiar that the desorption of the dye occurs only when UV light is irradiated to the electrode under the short circuit condition. The valence band hole created following the light absorption of $\mathrm{TiO}_{2}$ seems to play some role to desorb the dye from the surface of the film. No desorption of the dye detected nither by dipping the dye-modified $\mathrm{TiO}_{2}$ thin film into the electrolyte nor by the irradiation of visible light excluding the UV part nor by exposing the electrode under the simulated solar light containing UV at opencircuit condition. To explain this phenomenon, we propose the following as mechanism. When $\mathrm{TiO}_{2}$ absorbs UV light, an electron is excited to the conduction band, and a hole is formed in the valence band. In the case of open circuit, the electron-hole pair recombines. But in the case of short circuit, the electron can move to external circuit before recombination, and the hole may react with species at the semiconductor surface or in the electrolyte. If oxidized dyes react with holes before the regeneration by redox electrolyte, they may be decomposed by the $\mathrm{TiO}_{2}$ valence band hole. In short circuit condition with UV containing irradiation, such reaction can happen with dyes which have no contact with redox electrolyte. However, such reaction would end when the remaining dyes have contact with the redox electrolyte since such dyes are regenerated by the redox electrolyte before it reacts with the hole.

According to the absorption spectrum of the film after the treatment, the color of the film is very pale. It means that the light harvesting efficiency of the film is not sufficient to absorb the incident photons. Further optimization to establish the monolayer adsorption of the dye on $\mathrm{TiO}_{2}$ is thus required.

\section{Conclusion}

An Ru complex dye, E322, was synthesized and applied to dye-sensitized solar cells. Compared to N719, E322 has a broader absorption spectrum, and the extinction coefficient for E322 is about 3 times higher than N719. The cell with E322 showed very poor IPCE of $0.45 \%$ at $540 \mathrm{~nm}$ although it has a broader absorption and a higher extinction coefficient than N719. The reason of the low efficiency was caused by unmatched energy levels between the LUMO potential of the dye and the conduction band of the $\mathrm{TiO}_{2}$ and the aggregation and/or multilayer adsorption of the dye. Aggregated dye molecules block the contact between the active dye and the redox electrolyte, which leads to poor regeneration of the oxidized dye after the electron injection into the conduction band of $\mathrm{TiO}_{2}$. The efficiency increased dramatically, more than 10 times, after treating the cell with simulated solar light containing UV irradiation under short circuit condition. By this treatment, the aggregated dye molecules were removed from the surface of the electrode, and the conduction band of $\mathrm{TiO}_{2}$ was shifted toward more positive potential (by the adsorption of cation from the degradation of either aggregated dye or protons or cations in the redox electrolyte). These two phenomena enhanced the electron injection from the sensitizer to $\mathrm{TiO}_{2}$ and the regeneration reaction between the oxidized dye and redox electrolyte.

\section{Acknowledgments}

The authors thank the Swedish Energy Agency and the Knut and Alice Wallenberg foundation for financial support. K. Nonomura appreciates Professor Shogo Mori for fruitful discussion.

\section{References}

[1] B. O’Regan and M. Grätzel, "A low-cost, high-efficiency solar cell based on dye-sensitized colloidal $\mathrm{TiO}_{2}$ films," Nature, vol. 353, no. 6346, pp. 737-740, 1991.

[2] Md. K. Nazeeruddin, A. Kay, I. Rodicio, et al., "Conversion of light to electricity by cis-X2bis $\left(2,2^{\prime}\right.$-bipyridyl- $4,4^{\prime}$ dicarboxylate)ruthenium(II) charge-transfer sensitizers ( $\mathrm{X}=$ $\mathrm{Cl}-, \mathrm{Br}-, \mathrm{I}-, \mathrm{CN}-$, and SCN-) on nanocrystalline $\mathrm{TiO}_{2}$ electrodes," Journal of the American Chemical Society, vol. 115, no. 14, pp. 6382-6390, 1993.

[3] K.-J. Jiang, N. Masaki, J.-B. Xia, S. Noda, and S. Yanagida, "A novel ruthenium sensitizer with a hydrophobic 2-thiophen2-yl-vinyl- conjugated bipyridyl ligand for effective dye sensitized $\mathrm{TiO}_{2}$ solar cells," Chemical Communications, no. 23, pp. 2460-2462, 2006.

[4] D. Kuang, C. Klein, S. Ito, et al., "High-efficiency and stable mesoscopic dye-sensitized solar cells based on a high molar extinction coefficient ruthenium sensitizer and nonvolatile electrolyte," Advanced Materials, vol. 19, no. 8, pp. 1133-1137, 2007.

[5] P. Wang, S. M. Zakeeruddin, J. E. Moser, Md. K. Nazeeruddin, T. Sekiguchi, and M. Grätzel, "A stable quasi-solid-state dyesensitized solar cell with an amphiphilic ruthenium sensitizer and polymer gel electrolyte," Nature Materials, vol. 2, no. 6, pp. 402-407, 2003.

[6] C. S. Karthikeyan, H. Wietasch, and M. Thelakkat, "Highly efficient solid-state dye-sensitized $\mathrm{TiO}_{2}$ solar cells using donor-antenna dyes capable of multistep charge-transfer cascades," Advanced Materials, vol. 19, no. 8, pp. 1091-1095, 2007.

[7] Md. K. Nazeeruddin, F. de Angelis, S. Fantacci, et al., "Combined experimental and DFT-TDDFT computational study of photoelectrochemical cell ruthenium sensitizers," Journal of the American Chemical Society, vol. 127, no. 48, pp. 16835-16847, 2005. 
[8] K.-J. Jiang, J. Xia, N. Masaki, S. Noda, and S. Yanagida, "Efficient sensitization of nanocrystalline $\mathrm{TiO}_{2}$ films with high molar extinction coefficient ruthenium complex," Inorganica Chimica Acta, vol. 361, no. 3, pp. 783-785, 2008.

[9] C.-Y. Chen, S.-J. Wu, C.-G. Wu, J.-G. Chen, and K.-C. Ho, "A ruthenium complex with superhigh light-harvesting capacity for dye-sensitized solar cells," Angewandte Chemie International Edition, vol. 45, no. 35, pp. 5822-5825, 2006.

[10] D. Kuang, S. Ito, B. Wenger, et al., "High molar extinction coefficient heteroleptic ruthenium complexes for thin film dye-sensitized solar cells," Journal of the American Chemical Society, vol. 128, no. 12, pp. 4146-4154, 2006.

[11] F. Gao, Y. Wang, D. Shi, et al., "Enhance the optical absorptivity of nanocrystalline $\mathrm{TiO}_{2}$ film with high molar extinction coefficient ruthenium sensitizers for high performance dyesensitized solar cells," Journal of the American Chemical Society, vol. 130, no. 32, pp. 10720-10728, 2008.

[12] H. Choi, C. Baik, S. Kim, et al., "Molecular engineering of hybrid sensitizers incorporating an organic antenna into ruthenium complex and their application in solar cells," New Journal of Chemistry, vol. 32, no. 12, pp. 2233-2237, 2008.

[13] S. A. Haque, S. Handa, K. Peter, E. Palomares, M. Thelakkat, and J. R. Durrant, "Supermolecular control of charge transfer in dye-sensitized nanocrystalline $\mathrm{TiO}_{2}$ films: towards a quantitative structure-function relationship," Angewandte Chemie International Edition, vol. 44, no. 35, pp. 5740-5744, 2005.

[14] D. P. Hagberg, T. Edvinsson, T. Marinado, G. Boschloo, A. Hagfeldt, and L. Sun, "A novel organic chromophore for dyesensitized nanostructured solar cells," Chemical Communications, no. 21, pp. 2245-2247, 2006.

[15] A. Hagfeldt, G. Boschloo, H. Lindström, et al., "A system approach to molecular solar cells," Coordination Chemistry Reviews, vol. 248, no. 13-14, pp. 1501-1509, 2004.

[16] Md. K. Nazeeruddin, S. M. Zakeeruddin, R. HumphryBaker, et al., "Acid-base equilibria of (2,2'-bipyridyl-4,4'dicarboxylic acid)ruthenium(II) complexes and the effect of protonation on charge-transfer sensitization of nanocrystalline titania," Inorganic Chemistry, vol. 38, no. 26, pp. 62986305, 1999.

[17] A. Hagfeldt and M. Grätzel, "Molecular photovoltaics," Accounts of Chemical Research, vol. 33, no. 5, pp. 269-277, 2000.

[18] M. Grätzel, "Transition metal complexes as sensitizers for efficient mesoscopic solar cells," Bulletin of Japan Society of Coordination Chemistry, vol. 51, pp. 3-12, 2008.

[19] A. Hagfeldt, U. Björksten, and M. Grätzel, "Photocapacitance of nanocrystalline oxide semiconductor films: bandedge movement in mesoporous $\mathrm{TiO}_{2}$ electrodes during UV illumination," Journal of Physical Chemistry, vol. 100, no. 20, pp. 8045-8048, 1996.

[20] S. Ferrere and B. A. Gregg, "Large increases in photocurrents and solar conversion efficiencies by UV illumination of dye sensitized solar cells," Journal of Physical Chemistry B, vol. 105, no. 32, pp. 7602-7605, 2001.

[21] B. A. Gregg, S.-G. Chen, and S. Ferrere, "Enhanced dyesensitized photoconversion efficiency via reversible production of UV-induced surface states in nanoporous $\mathrm{TiO}_{2}$," Journal of Physical Chemistry B, vol. 107, no. 13, pp. 30193029, 2003.

[22] Y. Liu, A. Hagfeldt, X.-R. Xiao, and S.-E. Lindquist, "Investigation of influence of redox species on the interfacial energetics of a dye-sensitized nanoporous $\mathrm{TiO}_{2}$ solar cell," Solar Energy Materials and Solar Cells, vol. 55, no. 3, pp. 267-281, 1998.
[23] N.-G. Park, S.-H. Chang, J. van de Lagemaat, K.-J. Kim, and A. J. Frank, "Effect of cations on the open-circuit photovoltage and the charge-injection efficiency of dye-sensitized nanocrystalline rutile $\mathrm{TiO}_{2}$ films," Bulletin of the Korean Chemical Society, vol. 21, no. 10, pp. 985-988, 2000.

[24] K. Fredin, J. Nissfolk, G. Boschloo, and A. Hagfeldt, "The influence of cations on charge accumulation in dye-sensitized solar cells," Journal of Electroanalytical Chemistry, vol. 609, no. 2, pp. 55-60, 2007.

[25] G. Boschloo and A. Hagfeldt, "Photoinduced absorption spectroscopy of dye-sensitized nanostructured $\mathrm{TiO}_{2}$," Chemical Physics Letters, vol. 370, no. 3-4, pp. 381-386, 2003.

[26] G. Boschloo and A. Hagfeldt, "Photoinduced absorption spectroscopy as a tool in the study of dye-sensitized solar cells," Inorganica Chimica Acta, vol. 361, no. 3, pp. 729-734, 2008. 


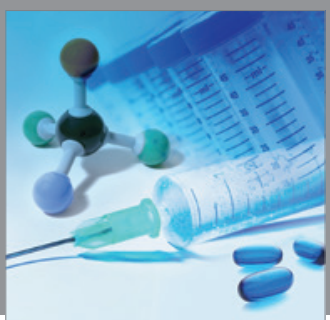

International Journal of

Medicinal Chemistry

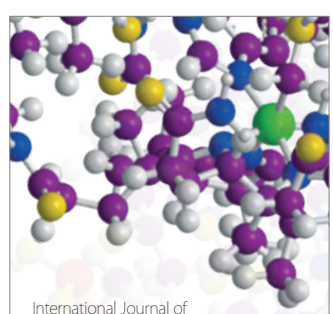

Carbohydrate Chemistry

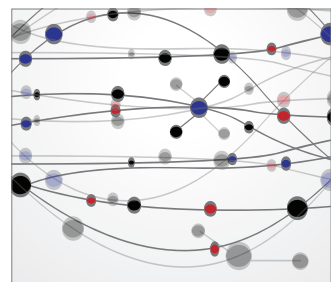

The Scientific World Journal
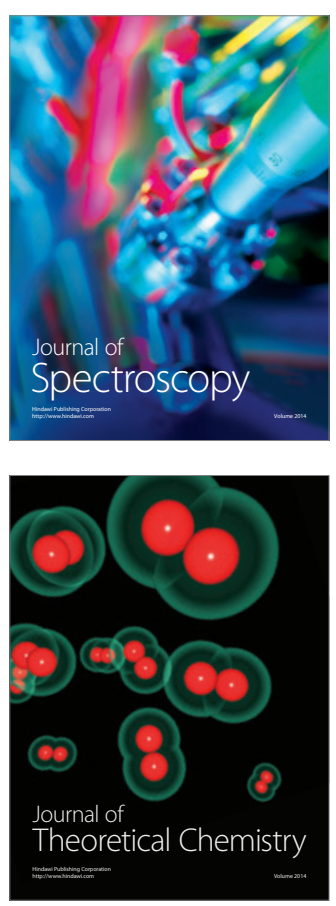
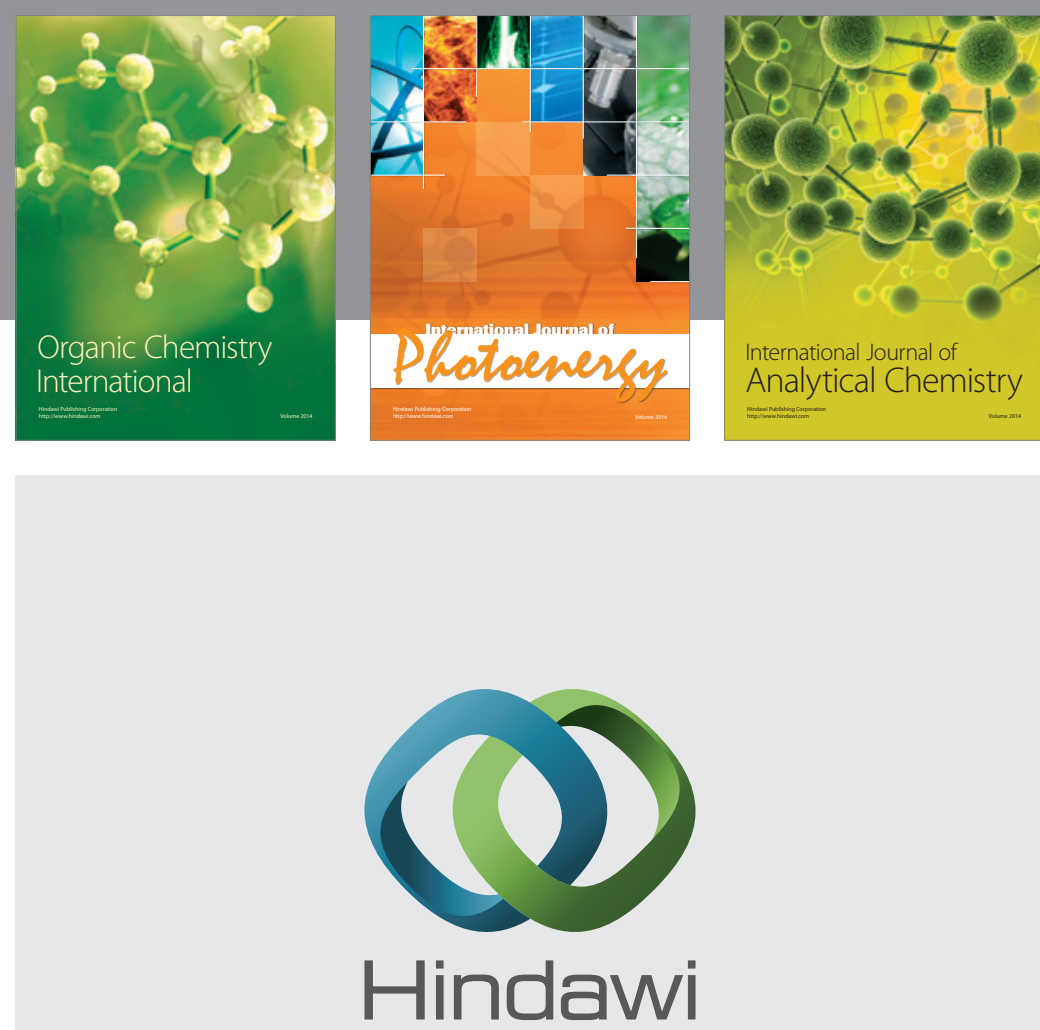

Submit your manuscripts at

http://www.hindawi.com
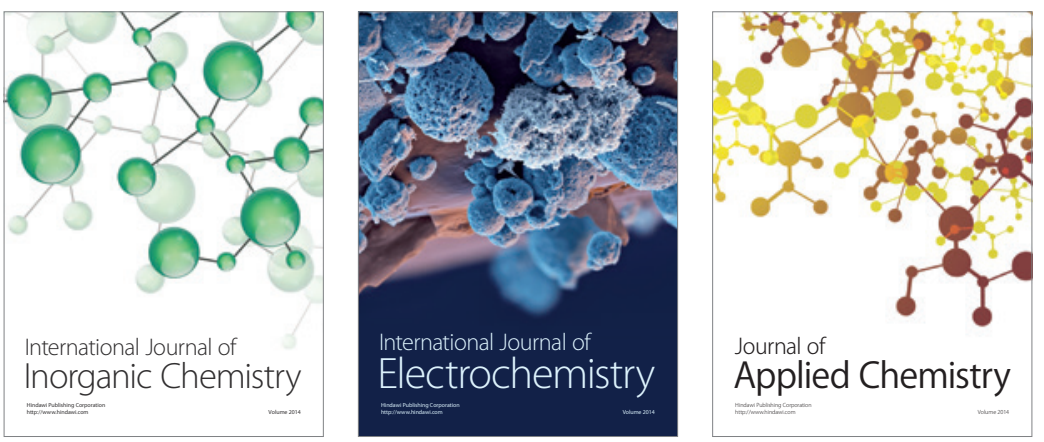

Journal of

Applied Chemistry
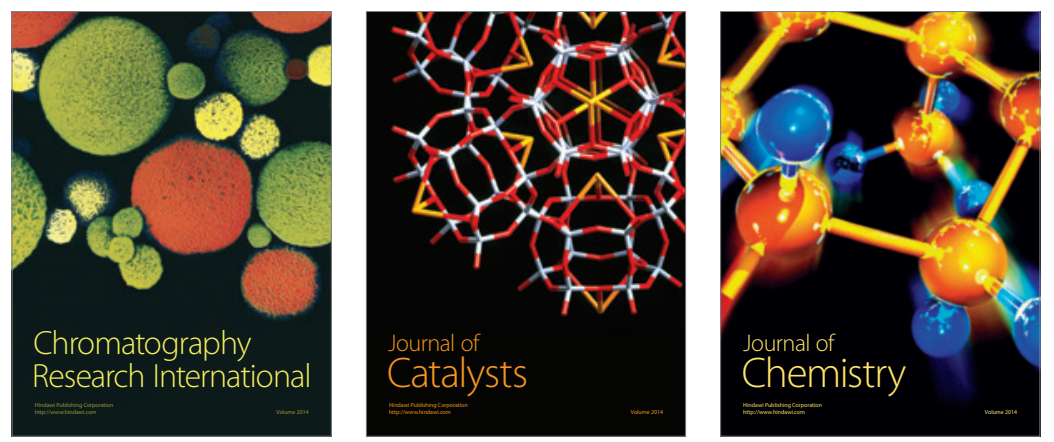
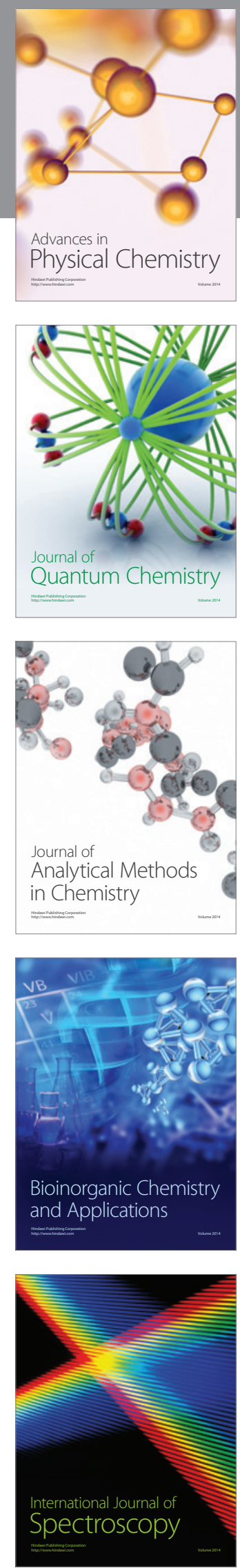